\title{
Application of library-independent microbial source tracking methods for identifying the sources of faecal contamination in coastal areas
}

\author{
M. Gourmelon ${ }^{1, *}$, M. P. Caprais ${ }^{1}$, C. Le Mennec ${ }^{1}$, S. Mieszkin ${ }^{1}$, C. Ponthoreau ${ }^{2}$ and M. \\ Gendronneau $^{2}$
}

${ }^{1}$ Ifremer, EMP, Laboratoire de Microbiologie, 29280 Plouzané, France

${ }^{2}$ Cap Atlantique, 44500 La Baule, France

*: Corresponding author : M. Gourmelon, email address : Michele.Gourmelon@ifremer.fr

M. Gendronneau, email address : maud.gendronneau@cap-atlantique.fr

\begin{abstract}
Faecal contamination sources were identified in coastal areas around the Guerande-Atlantique peninsula using two microbial source tracking (MST) methods: (i) Bacteroidales host-specific 16S rRNA gene markers measured by real-time PCR and (ii) F-specific bacteriophage (FRNAPH) genotyping. Both methods were used on 63 water samples from 7 water courses. HF183 marker and bacteriophage genogroup II (FRNAPH II) were detected in all water samples and in the majority of water samples, respectively, from La Torre stream (W5), Piriac (W2), R2000 (W3) and Mazy (W7) rain water drains, and also detected, less frequently, in Le Nau drain (W4), suggesting contamination by human faecal sources at these sites. These human markers were weakly detected in Pouliguen channel (W6). Furthermore, BacR and bacteriophage genogroup I (FRNAPH I) were also detected, but at lower concentration and frequency. So, site W6 seems to be contaminated by multiple sources, though mainly human. Finally, BacR was detected twice in Pont d'Armes channel (W1), whereas HF183 was not detected. FRNAPH I and II were detected in only 3 out of 12 water samples. Site W1 seems mainly contaminated by animal sources. As a result of our findings, actions were taken to remediate water and shellfish quality.
\end{abstract}

Keywords: Bacteroidales; F-specific RNA bacteriophages; faecal bacterial indicators; microbial source tracking; water 


\section{Introduction}

Faecal pollution of coastal environments affects recreational water, shellfish quality and safety. It can also cause economic losses from bathing restrictions and closure of shellfish harvesting areas. Effective resource management and remediation requires contamination sources to be identified. Indeed, the revised Bathing Water European Directive (2006/7/EC) has made the bathing water classification system more stringent, and bathing water profiles are now required to identify sources of faecal contamination. In addition, revisions of EU directive concerning shellfish (Hygiene 3 Regulation (EC) $\mathrm{N}^{\circ} 854 / 2004$ ) go through the best means of assessment for potential faecal sources upstream of shellfish farming areas.

Microbial Source Tracking (MST) can identify the origins of faecal pollution in environmental waters and is particularly useful for non-point or multiple sources. Promising library-independent MST methods based on molecular and cultural methods, such as quantification of host-specific Bacteroidales 16S rRNA gene markers by real-time PCR and detection and genotyping of Fspecific RNA bacteriophages (FRNAPH), have been developed (Hsu et al., 1995; Beekwilder et al., 1996; Seurinck et al., 2005; Reischer et al., 2006) and validated on French faecal samples (Gourmelon et al., 2007; Mieszkin et al., 2009). The FRNAPH are classified into four genogroups, of which genogroups II and III are generally found in human sewage and genogroups I and IV are generally found in animal wastes (Schaper et al., 2002; Ogorzaly et al., 2006; Gourmelon et al., 2007).

Coastal areas of Guerande-Atlantique Peninsula in western France include popular bathing areas and commercial and recreational shellfish areas. Most bathing areas are A-category whereas shellfish areas are B-category according to directives 2006/7/EC and 91/492/EEC. Briefly, coastal bathing waters were classified as A-category or "excellent" quality if the $95 \%$ percentile values for intestinal Enterococci and Escherichia coli (E. coli) were equal to or better than 100 and 250 CFU (Colony Forming Unit) per $100 \mathrm{ml}$, respectively (2006/7/EC), in the bathing water quality database for the last assessment period. The shellfish harvesting areas were classified as B-category according to European legislation (European Directive 91/492/EEC); this means that the shellfish were found to contain between 230 and $4600 \mathrm{E}$. coli per $100 \mathrm{~g}$ total flesh and must be depurated for $\geq 48 \mathrm{~h}$ in good quality water prior to sale.

Guerande-Atlantique Peninsula covers $140 \mathrm{~km}^{2}$, with a highly urbanised coast and around 65000 inhabitants (quadrupled in summer). The area also has cattle and sheep rearing on the watersheds, riding stables and many seabirds roosting in certain sites. Unfortunately, high Escherichia coli values in shellfish (> 4600 E. coli per $100 \mathrm{~g}$ of total flesh, corresponding to Ccategory shellfish harvesting areas) have led to temporary or year-round closures of some shellfish-harvesting areas in recent years, as shellfish from C-category recreational shellfish harvesting areas cannot be harvested for consumption. Furthermore, shellfish from professional Ccategory areas have to be depurated for at least two months prior to sale. Such closures have a particularly serious impact on tourism and shellfish-farming activities. Corrective actions, therefore, need to be taken to decrease faecal pollution inputs to coastal areas.

CAP Atlantique ("Communauté d'Agglomération de la Presqu'île de Guérande Atlantique" - Urban Community of Guerande-Atlantique Peninsula) is a public body for cooperation between local towns on the peninsula; it manages aquatic environment quality and sanitation issues. This organization wanted to identify the potential sources of contamination using MST tools in order to understand and remediate water quality problems occuring in shellfish harvesting areas.

As a first step, CAP Atlantique tried to identify the watercourses responsible for the faecal microbial pollution observed in shellfish-harvesting areas of the Guerande-Atlantique peninsula, by enumerating $E$. coli concentrations in water samples from many watercourses in this area. This action has succeeded in identifying some of the sources of faecal contaminations and some corrective actions were made. However, faecal contaminations were still observed in some 
locations. So, as a second step, an investigation of the origin of the faecal contamination was planned, using MST tools that were developed or selected in a microbiology laboratory at Ifremer. The aim and main objective of this study was, therefore, to identify fecal pollution sources in water courses discharging into coastal areas of the Guerande-Atlantique peninsula using the following MST tools, validated in previous studies (Seurinck et al., 2005; Reischer et al., 2006; Gourmelon et al., 2007; Mieszkin et al., 2009): (i) host-specific fecal Bacteroidales 16S rRNA gene markers and (ii) FRNAPH genotyping. The faecal markers were compared with $E$. coli counts, as this is the current fecal indicator bacteria, especially in shellfish harvesting areas. This study presents an opportunity to test the utility of MST tools in a research strategy to identify the sources of faecal pollution in coastal areas.

\section{Methods}

\section{Collection and preparation of water samples}

A total of 63 water samples were collected from September 2006 to October 2008 from 7 water courses on the Guerande-Atlantique peninsula. Le Nau (W4), Piriac (W2), R2000 (W3) and Mazy (W7) rain water drains are located in urban areas. La Torre stream (W5) and Pouliguen channel (W6) are also mainly in urban areas, whereas Pont d'Armes channel (W1) is mainly in an agricultural cattle-rearing area (Fig. 1). The number of samples differed (from 5 to 20) according to sampling site, as the main objective was to identify the sources of contamination quickly as to take corrective action and focus on sites where contaminations were more difficult to identify. Monthly sampling was mainly done. Furthermore, previous investigations in these watercourses, based on $E$. coli enumeration for example, allowed us to select the most appropriate sampling dates, sites and conditions.

All samples were placed in sterile containers and transported in insulated coolers. The samples were prepared for analyses immediately upon arrival at the laboratory: (i) water filtration for Bacteroidales markers, (ii) F-specific RNA bacteriophage (FRNAPH) enumeration and isolation of bacteriophages directly or after concentration, and (iii) $E$. coli enumeration by standard microplate method. 


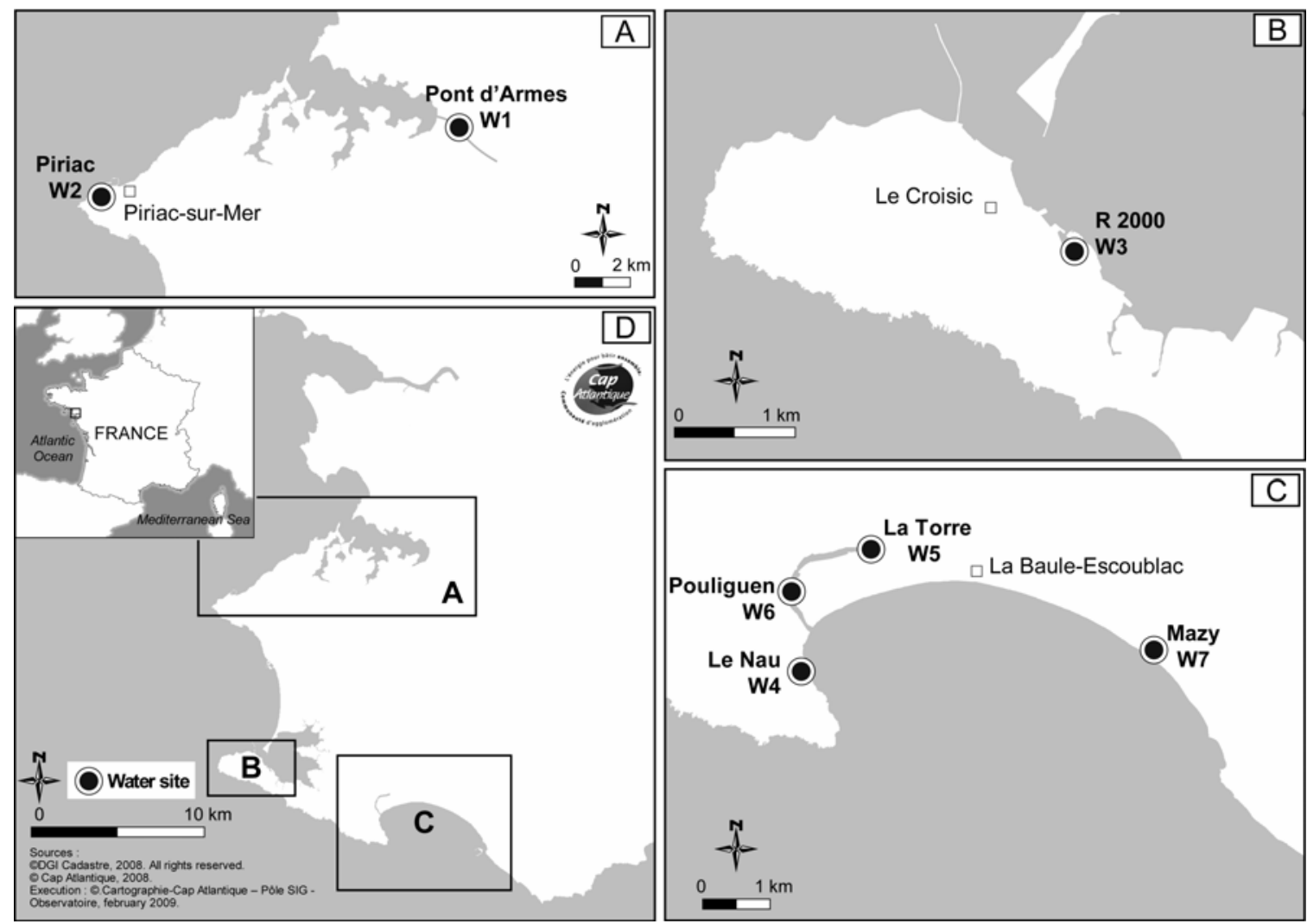

Figure 1 Locations of the seven water sampling sites on Guerande-Atlantique peninsula, France

Quantification of Bacteroidales markers

Approximately $200 \mathrm{ml}$ water were filtered through $0.22 \mu \mathrm{m}$ Nuclepore membrane filters (Whatman, Scleicher and Schuell, Germany). Filters were then placed in $0.5 \mathrm{ml}$ of GITC buffer ( $5 \mathrm{M}$ guanidine isothiocyanate, $100 \mathrm{mM}$ EDTA [pH = 8.0], $0.5 \%$ Sarkosyl) and stored at $-20^{\circ} \mathrm{C}$. DNA was extracted using the DNeasy Tissue kit (Qiagen, Courtaboeuf, France) with some modifications as described in Mieszkin et al. (2009).

All-Bacteroidales (AllBac) primers and probe from Layton et al. (2006) were used to amplify total Bacteroidales 16S rRNA genes. Detection of human- and ruminant-specific Bacteroidales 16S rRNA gene markers (HF183 and BacR) was performed with the primers and probe described by Seurinck et al. (2005) and Reischer et al. (2006).

Real-time PCR for the AllBac and BacR markers were performed using TaqMan ${ }^{\circledR}$ Brilliant QPCR Core reagent kit (Stratagene), whereas, for HF183, the Brillant SYBR-Green ${ }^{\circledR}$ QPCR Master Mix (Stratagene) was used. Amplifications were performed using a Stratagene MX $3000 \mathrm{P}$ with version 4 software. Each reaction was run in triplicate: 1 cycle at $95{ }^{\circ} \mathrm{C}$ for $10 \mathrm{~min}$ followed by 40 cycles of $95{ }^{\circ} \mathrm{C}$ for $15 \mathrm{~s}, 60{ }^{\circ} \mathrm{C}$ for $1 \mathrm{~min}$. For SYBR-Green ${ }^{\circledR}$ amplifications, a dissociation step was added to improve amplification specificity. All reactions were carried out in a final volume of $25 \mu \mathrm{l}$ with appropriate concentrations of primers and probe, as described in Mieszkin et al. (2009).

The presence/absence of PCR inhibitors was verified using an Internal Positive Control (IPC; AppliedBiosystem, France). Samples were diluted if inhibitors were present. Negative controls (no template DNA) were performed in triplicate for each run.

Plasmid DNA for standard curves was extracted with QIAquick Miniprep Extraction Kit (Qiagen). Linear forms of plasmids were obtained with Notl enzyme (Roche Diagnostics) in a final volume of $50 \mu \mathrm{l}$ for $3 \mathrm{~h}$ at $37^{\circ} \mathrm{C}$. For marker quantification, standard curves were generated from serial dilutions of a known concentration of plasmid DNA. Threshold cycles (Ct) were plotted against 165 rRNA copy numbers. For AllBac, BacR and HF183, bovine and human plasmid DNA containing 
partial 16S rRNA gene sequence inserts were used as standards at ten-fold dilutions ranging from $5 \times 10^{7}$ to $5 \times 10^{0}$ copies per real-time PCR, with a quantification limit of 5 target copies per reaction.

Consequently, the lower quantification limit for the AllBac, BacR and HF183 markers was approximately $3 \log _{10}$ copies per 100 ml water.

\section{Detection of F-specific RNA bacteriophages}

FRNAPH were enumerated by the double-agar-layer method (ISO 10705-1. 2001) with Salmonella typhimurium strain WG49, using a concentration step if necessary (Mendez et al., 2004; Gourmelon et al., 2007). The results were expressed as Plaque Forming Units (PFU) per $100 \mathrm{ml}$ water, with a detection limit of $10 \mathrm{PFU} / 100 \mathrm{ml}$ water.

Plaques were transferred onto nylon membranes and denaturation and neutralisation performed as described by Schaper and Jofre (2000). For samples with low bacteriophage concentrations, single plaques were transfered individually using the protocol described by Long and Sobsey (2004). Hybridizations were performed using oligonucleotide probes designed by Hsu et al. (1995) to determine plaque numbers for each FRNAPH genotype (I, II, III and IV) (Beekwilder et al., 1996). Probe-target hybrids were detected using the chemiluminescent assay with CDP-Star enzyme substrate (Roche Diagnostics). Only results with at least 20 successfully genotyped plaques were considered. Indeed, due to the statistical variation in tests for FRNAPH, results $<20$ PFU were considered inconclusive (Stapleton et al., 2007). Results are expressed in percentages of human or animal genogroups / total FRNAPH isolated.

\section{Enumeration of E. coli}

E. coli enumerations were performed by the microplate method (EN ISO 9308-3. 1999) with a detection limit of < 15 MPN (Most Probable Number) per 100 ml water.

\section{Rainfall data}

Rainfall data were obtained from the Guerande Météo-France station.

\section{Statistical analyses}

All statistical analyses were performed using STATISTICA version 6.1 (StatSoft France) on the $\log _{10}$-transformed values of microorganism concentrations. A Pearson's product moment correlation analysis was used to examine the relationships between $E$. coli and AllBac concentrations, between E. coli and FRNAPH concentrations, and between AllBac and FRNAPH concentrations. Principal Component analysis (PCA) was used to give an overview of the data structure (microbiological parameters and rainfall).

\section{RESULTS AND DISCUSSION \\ Concentrations of total Bacteroidales marker, F-specific RNA bacteriophages and E. coli in water samples, and correlation between microbiological targets.}

Concentrations of $E$. coli ranging from 2.3 to $6 \log _{10}$ MPN per $100 \mathrm{ml}$ and FRNAPH from 1.3 to 3.8 $\log _{10}$ PFU per $100 \mathrm{ml}$ were found in $90 \%$ and $62 \%$ of water samples, respectively, whereas AllBac was quantified in $98 \%$ water samples with concentrations ranging from 4.4 to $7.7 \log _{10}$ copies per $100 \mathrm{ml}$.

Concentrations of these indicators varied with sampling site and date. Indeed, weaker median concentrations were obtained for E. coli, FRNAPH and the AllBac marker at sites W1 and W6 (2.6 and $2.8 \log _{10}$ MPN per $100 \mathrm{ml} ;<1$ and $1 \log _{10}$ PFU per $100 \mathrm{ml} ; 5.0$ and $5.1 \log _{10}$ copies per $100 \mathrm{ml}$, respectively) but concentrations were high at sites W2 and W3 (3.9 and $4.3 \log _{10}$ MPN per $100 \mathrm{ml}$; 2.7 and $2.8 \log _{10}$ PFU per $100 \mathrm{ml} ; 7.2$ and $6.7 \log _{10}$ copies per $100 \mathrm{ml}$, respectively), and sites W4, W5 and W7 showed intermediate values (Table 1; Fig. 2).

An interesting feature of this study is that significant positive relationships between $E$. coli and AllBac concentrations $(r=0.6613 ; p<0.0001)$, between $E$. coli and FRNAPH concentrations 
$(\mathrm{r}=0.5755 ; p<0.0001)$ and between AllBac and FRNAPH concentrations $(\mathrm{r}=0.6981 ; p<0.0001)$ were obtained using Pearson's correlation analysis (Fig. 2). Contreras-Coll et al. (2002) also found a slight correlation between bacteriophages and $E$. coli in bathing waters in Europe, and Ogorzaly et al. (2009) a positive correlation between the concentrations of FRNAPH II and E. coli in river water samples. Savichtcheva et al. (2007) found a positive correlation between Bacteroides 16S rRNA gene markers and coliforms. To our knowledge, our study is the first comparing these two alternative faecal indicators in water courses.

Results were confirmed by Principal Component Analysis performed with microbiological variables and rainfall data (Fig. 3). The variability explained by the first (F1) and the second (F2) factorial axes are respectively $58.8 \%$ and $25 \%$, thus yielding a first plane (F1, F2) that summarizes $83.8 \%$ of the total information in the data. The graph of the variables on plane F1, F2 shows that all of the variables considered are well represented with the respect to the correlation circle, allowing a sound interpretation and a simple synopsis of the correlation patterns. The first factorial axis (i.e., F1) is positively correlated with the microbiological variables: AllBac marker, FRNAPH and E. coli. The second factorial axis (i.e., F2) is positively correlated with rainfall. Thus, rainfall was weakly correlated with E. coli and not correlated with FRNAPH or AllBac.

Figure 2 Relations of $E$. coli concentrations with total Bacteroidales (AllBac) (A) and with F-specific RNA bacteriophages (FRNAPH) (B) in water samples. Microbiological parameter concentrations


and W7 (०).

(A)

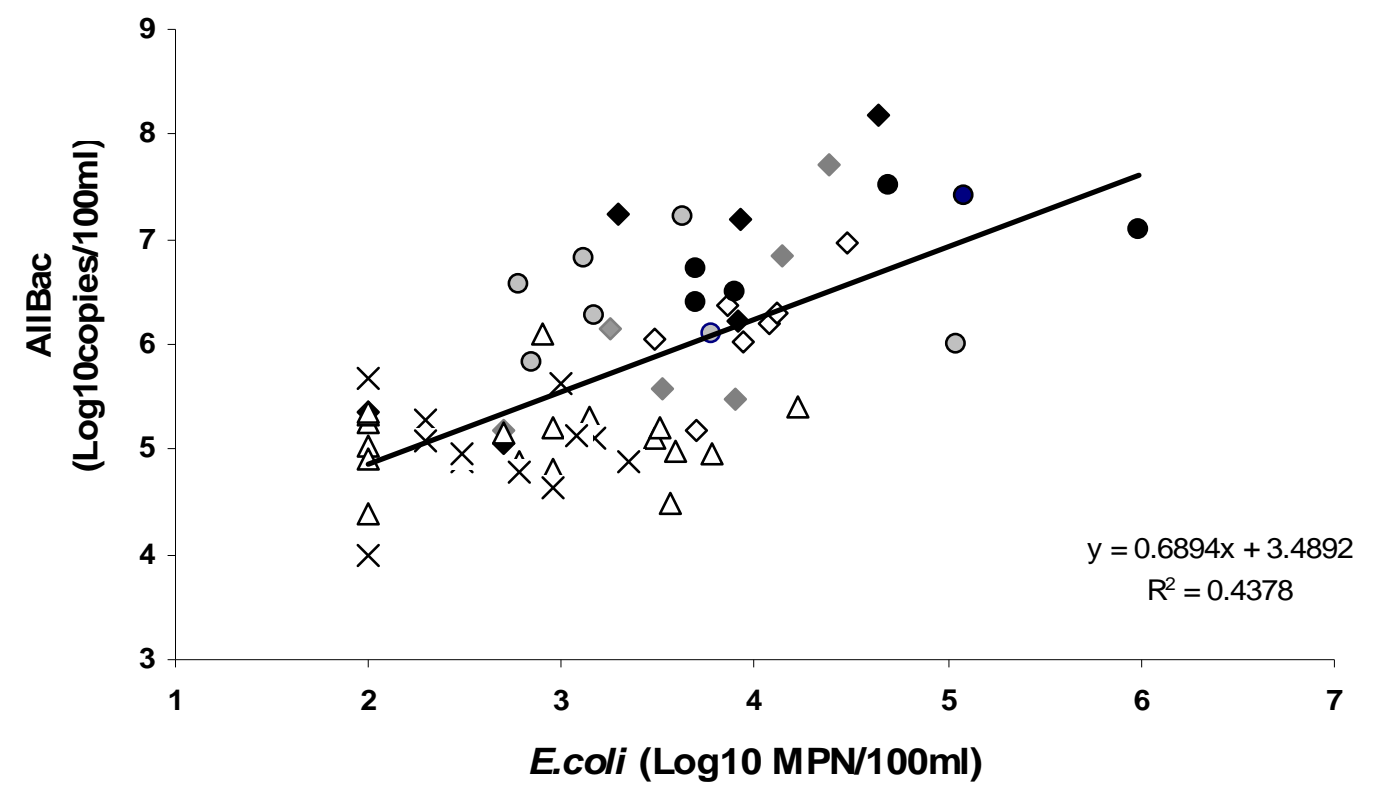

(B) 


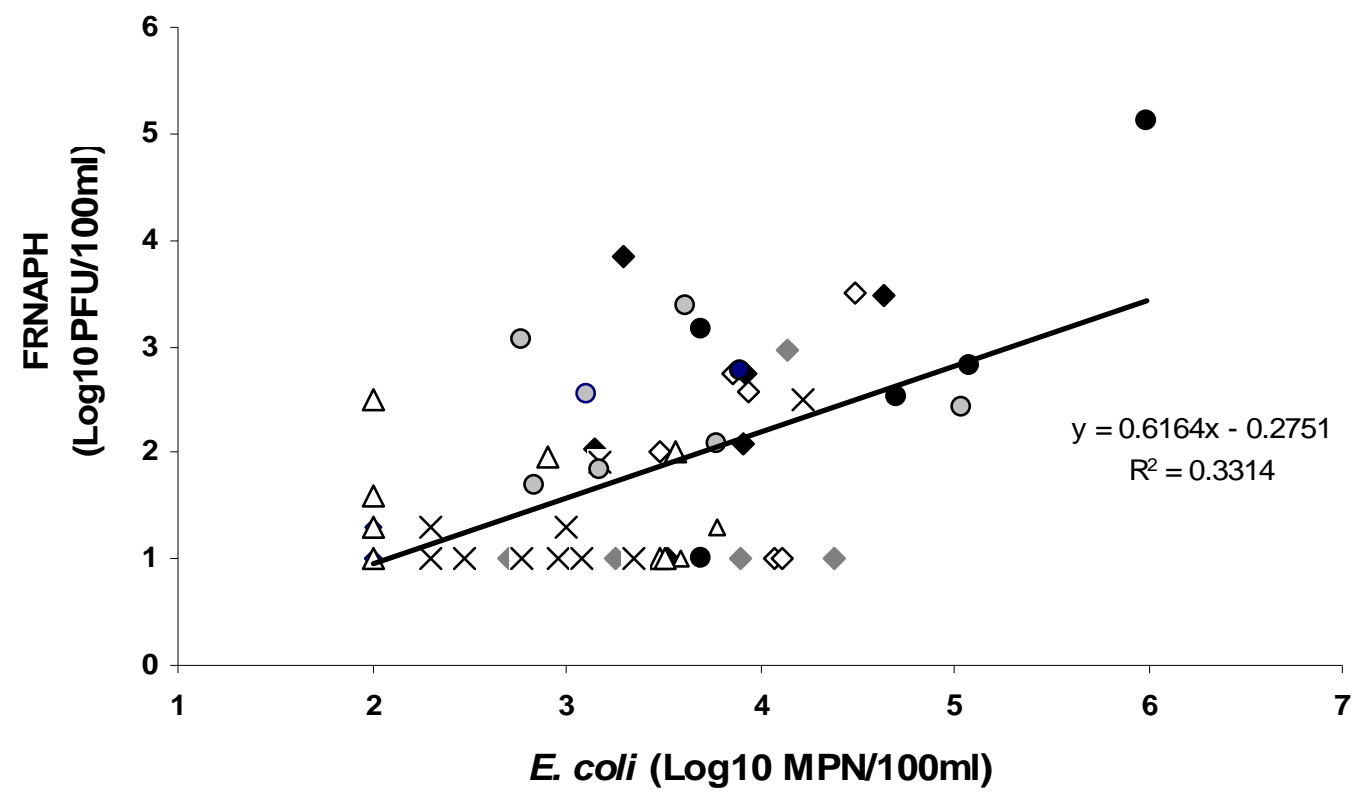

Figure 3 Principal component analysis on microbiological variables plus rainfall: graph of the variables on plane F1, F2.

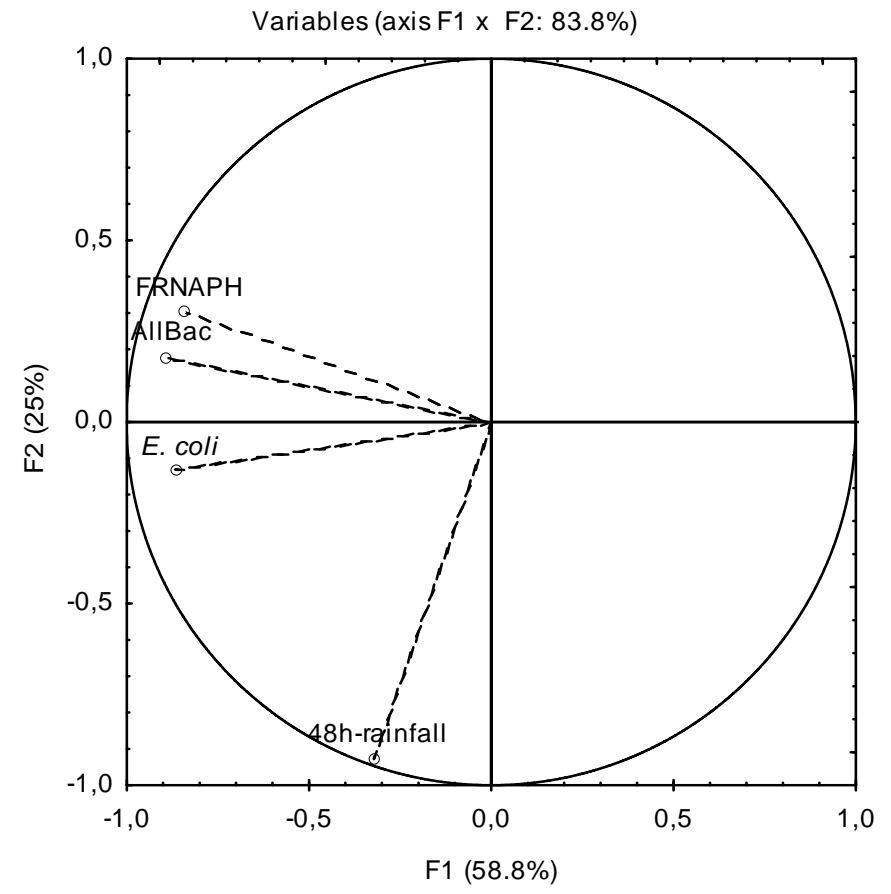

Detection of host-specific Bacteroidales markers and human and animal genotypes of Fspecific RNA bacteriophages

Results from human- (HF183) and ruminant- (BacR) Bacteroidales markers and of human (II and III) and animal (I and IV) genogroups of FRNAPH in the water samples from the 7 water courses are presented in table 1.

At least one host-specific Bacteroidales marker was detected in $66 \%$ of water samples and quantified in $48 \%$ of water samples, whereas isolates of FRNAPH were detected, directly or after 
concentration, and genotyped in $68 \%$ of water samples (with $57 \%$ of water samples with $>20$ phages genotyped and $11 \%$ of water with $<20$ phages).

HF183 marker and bacteriophage genogroup II (FRNAPH II) were detected in all water samples and in the majority of water samples, respectively, in La Torre stream (W5), Piriac (W2), R2000 (W3) and Mazy (W7) rain water drains (Tab. 1). Median HF183 concentrations ranged from 3.2 to $5.0 \log _{10}$ copies per $100 \mathrm{ml}$ water and the median percentage of FRNAPH II ranged from 57 to 100 \%. The HF183 marker and FRNAPH II were also detected in Le Nau drain (W4), but less frequently. These results suggest that human faecal sources contaminated these sites.

HF183 and FRNAPH II were often detected at weak concentrations and in high percentages, respectively, in water from Pouliguen channel (W6). Furthermore, BacR and FRNAPH I were also detected, but at lower concentration and frequency (Tab. 1). So, site W6 seems to be contaminated by multiple sources, mainly from humans.

Finally, BacR was detected twice in Pont d'Armes channel (W1), at concentrations of 3.5 and 3.6 log copies per $100 \mathrm{ml}$ water, whereas HF183 was not detected. FRNAPH were detected in only 5 out of 12 water samples and sufficient FRNAPH isolates $(>20)$ for conclusive results were obtained in only 3 samples with mainly FRNAPH I and, in a lesser extent, FRNAPH II in these cases. The site W1 seems to be mainly contaminated by animal sources. As BacR was detected, cattle and ovine rearing upstream could be a potential animal faecal source.

In the present study, human-specific Bacteroidales marker HF183 was quantified in $44.4 \%$ of samples with concentrations from 3 to $6.2 \log _{10}$ copies per $100 \mathrm{ml}$, whereas ruminant-specific Bacteroidales marker was only quantified in $8 \%$ of samples, at concentrations from 3 to $3.8 \log _{10}$ copies per $100 \mathrm{ml}$, suggesting that the main faecal contamination on Guerande-Atlantique Peninsula comes from human sources. When these markers were previously applied in another French catchment in France (Daoulas, Brittany, Mieszkin et al., 2009), they showed mainly bovine faecal contamination, as higher concentrations of BacR (from 4.1 to $6 \log _{10}$ copies per $100 \mathrm{ml}$ water) and weaker concentrations of HF183 (from 3.6 to $4.4 \log _{10}$ copies per $100 \mathrm{ml}$ water) were found. Similar concentrations of BacR were observed in water samples from a karstic spring catchment in Austria during a monitoring programme with a higher frequency detection rate (Reischer et al., 2008); likewise, similar concentrations of HF183 marker were found in river waters in Belgium (Seurinck et al., 2006).

In this study, two complementary MST methods were chosen to determine the origin of faecal pollution in water, so that we could have more confidence in our conclusions. In fact, using different MST methods simultaneously has been recommended to be the best solution for properly identifying microbial sources in a specified area (Gilpin et al., 2003; Blanch et al., 2004). Although conventional host-specific Bacteroidales markers and genotyping of F-specific bacteriophages have been applied together in previous studies (Gourmelon et al., 2007; Stapleton et al., 2007), this is the first study associating real-time detection of host-specific Bacteroidales markers and genotyping of bacteriophages. The latter method also suggested mainly faecal contamination from human sources around Guerande-Atlantique Peninsula, as human genogroups only were detected in $64 \%$ of the samples and both human and animal genogroups (mainly FRNAPH II and to a lesser extent FRNAPH I) were detected in $28 \%$ of the samples. Considering all FRNAPH isolated in this study, genogroups II and I were the main genogroups isolated in these watercourses with $76.7 \%$ and $12.1 \%$ of total FRNAPH, respectively. In comparison, genogroups III and IV were only detected four times and once, respectively, representing $<1 \%$ of total FRNAPH. A few percent of FRNAPH were not of genogroups I-IV. These results are in agreement with those of Cole et al. (2003) and Love and Sobsey (2007) where genogroups III and IV were also infrequently detected. Interestingly, these two methods agreed on the identification of the type of faecal pollution in each watercourse investigated, and results from HF183 and FRNAPH II and III were the same in $71.5 \%$ of water samples tested (data not shown). 
As a result of our findings, action was taken in Guerande-Atlantique Peninsula. Firstly, as W5 water samples showed human contamination, water sanitation testing (by sanitary inspections) was done at this site to identify houses not connected to public wastewater networks. These houses have now been connected to the sewage network, which has improved the microbial water quality of this rain water drain. For downstream site W6, results showed animal contamination in addition to human contamination, so in situ investigations were performed and allowed us to identify one main faecal pollution source - a riding stable. Before this study, only human wastes were suspected to be responsible for faecal pollution at this sampling site. Actions have since been performed to bring horse waste discharge up to standard by connecting the stables to the sewage network and thus prevent effluents from entering the watercourse. As W2, W3, W4 and W7 rainwater drains were found to be contaminated by human sources, although separate from wastewater treatment networks, actions consisted of identifying houses where toilets were not yet connected and then connecting these houses to wastewater networks. Finally, for site W1, a working group has been created (farmers, town council, etc.) to identify the best actions.

Table 1 Medians and ranges of microbiological parameters such as E. coli, general (AllBac), human- (HF183) and ruminant- (BacR) specific Bacteroidales markers and human and animal genotypes of F RNA specific bacteriophages) determined in water samples $(n=63)$ collected in 7 watercourses that could impact the microbial quality of coastal waters of the Guerande-Atlantique peninsula.

\begin{tabular}{|c|c|c|c|c|c|c|c|c|c|}
\hline Site & $\begin{array}{l}\text { Sampling } \\
\text { period }\end{array}$ & & E. coli ${ }^{\mathrm{a}}$ & $\underset{a}{\text { AllBac }}$ & FRNAPH $^{a}$ & $\mathrm{HF} 183^{\mathrm{a}}$ & $\mathrm{BacR}^{\mathrm{a}}$ & $\begin{array}{c}\text { Human } \\
\text { ofERduper } \\
\text { (II and III) (\%) }\end{array}$ & $\begin{array}{c}\text { Animal genotype } \\
\text { of FRNAPH } \\
(I \text { and IV) (\%) }\end{array}$ \\
\hline \multirow[t]{2}{*}{ W1 } & September & Median $^{5}$ & 2.6 & 5.0 & $<1$ & $<3$ & $<3$ & 35 & 60 \\
\hline & 2006 & Range & $<2-3.3$ & $4.6-5.7$ & $<1-1.9$ & $<3$ & $<3-3.6$ & $4-71$ & $29-96$ \\
\hline$n=12$ & October & $N^{\mathrm{c}}$ & 11 & 11 & 5 & 0 & 2 & 3 & 3 \\
\hline \multirow{2}{*}{ W2 } & Eabouary to & Median & 3.9 & 7.2 & 2.7 & 5.0 & $<3$ & 67 & 0 \\
\hline & June 2007 & Range & $2.7-4.6$ & $5.1-8.2$ & $<1-3.8$ & D-6.2 & $<3-D$ & $67-100$ & 0 \\
\hline$n=5$ & & $\mathrm{~N}^{\mathrm{c}}$ & 5 & 5 & 4 & 4 & 0 & 3 & 0 \\
\hline \multirow[t]{2}{*}{ W3 } & November & Median & 4.3 & 6.7 & 2.8 & 3.9 & $<3$ & 100 & 0 \\
\hline & 2007 to May & Range & $3.7-6$ & $6.4-7.5$ & $1-5.1$ & $<3-4.7$ & $<3$ & $58-100$ & $0-41.6$ \\
\hline$n=6$ & 2008 & $\mathrm{~N}^{\mathrm{c}}$ & 6 & 6 & 6 & 5 & 0 & 6 & 2 \\
\hline \multirow[t]{2}{*}{ W4 } & February to & Median & 3.7 & 5.6 & $<1$ & $<3$ & $<3$ & 91 & 9 \\
\hline & June 2007 & Range & $2.7-4.4$ & $5.2-6.7$ & $<1-3.0$ & $<3-3.3$ & $<3-D$ & 91 & 9 \\
\hline$n=6$ & & $\mathrm{~N}^{\mathrm{c}}$ & 6 & 6 & 1 & 2 & 0 & 1 & 1 \\
\hline \multirow[t]{2}{*}{ W5 } & February to & Median & 3.9 & 6.2 & 2 & 4.0 & $<3$ & 57 & 3 \\
\hline & September & Range & $3.5-4.5$ & $5.2-7.0$ & $<1-3.5$ & $<3-5.1$ & $<3-3.4$ & $5-97$ & $0-95$ \\
\hline$n=7$ & 2007 & $\mathrm{~N}^{\mathrm{c}}$ & 7 & 7 & 6 & 4 & 1 & 5 & 2 \\
\hline \multirow[t]{2}{*}{ W6 } & September & Median & 2.8 & 5.1 & 1 & D & $<3$ & 100 & 0 \\
\hline & 2006 to & Range & $<2-4.2$ & $4.4-6.1$ & $<1-2.5$ & $<3-4.0$ & $<3-3.8$ & $12-100$ & $3-75$ \\
\hline$n=20$ & October & $\mathrm{N}^{\mathrm{c}}$ & 15 & 20 & 10 & 6 & 2 & 10 & 5 \\
\hline \multirow[t]{2}{*}{ W7 } & 1008mber & Median & 3.2 & 6.3 & 2.4 & 3.2 & $<3$ & 100 & 0 \\
\hline & 2007 to May & Range & $2.8-5.1$ & $5.8-7.2$ & $1.7-3.4$ & D-6.1 & $<3$ & $93-100$ & $0-7$ \\
\hline$n=7$ & 2008 & $N^{c}$ & 7 & 7 & 7 & 6 & 0 & 7 & 1 \\
\hline
\end{tabular}

${ }^{a}$ Concentrations of E. coli, Bacteroidales markers (AllBac, HF183 and BacR) and FRNAPH are expressed in $\log _{10}$ MPN/ $100 \mathrm{ml}$, in $\log _{10}$ copies par $100 \mathrm{ml}$ and in $\log _{10}$ PFU / $100 \mathrm{ml}$ water, respectively.

$\mathrm{b}$ The median value of percentages of human and animal genogroups / total number of isolated $F$ RNA specific bacteriophages corresponds to the median value of the percentage of human (FRNAPH II and III) or animal (FRNAPH I and IV) genogroups / total number of isolated F RNA specific bacteriophages for each water sample at a given sampling site

${ }^{\mathrm{c}}$ Number of results > quantification limit for each microbiological parameter and site, and, for human and animal genotypes of FRNAPH, number of samples where at least 20 FRNAPH were isolated and genotyped by sample. D: detected; positive results were obtained in at least two out of three repeated experiments.

\section{CONCLUSIONS}


Application of complimentary MST methods on water samples allowed the origin of faecal contamination to be identified in water courses that could contaminate bathing and shellfishharvesting areas around Guerande-Atlantique Peninsula. From these results, remedial action was taken (improvements of water discharged from riding stables, rainfall drains etc.) and shellfish microbial quality improved. In particular this study has allowed the design of research strategies to identify the origin of faecal pollution in coastal areas and decrease it in main three steps: (i) preliminary identification of the main points responsible for faecal pollution, using the classical faecal indicator E. coli, unable to distinguish human from animal sources; (ii) application of MST tools at selected sampling sites; (iii) discussions with local actors to improve local practices and bring up to standard of individual or communal outfalls.

This study shows that these methods are promising tools for identification and management of faecal contamination in rivers and coastal areas. The use of these methods seems particularly suitable for the establishment of bathing water profiles required by European Directive (2006/7/CE). However, methodological developments are still needed to apply these methods to water that is only weakly contaminated, such as bathing waters, to apply them to shellfish and to have a greater array of host-specific markers.

\section{References}

Beekwilder J., Nieuwenhuizen R., Havelaar A.H. and van Duin J. (1996). An oligonucleotide hybridization assay for the identification and enumeration of F-specific RNA phages in surface water. Journal of Applied Bacteriology, 80 (2), 179-186.

Blanch A. R., Belanche-Munoz L., Bonjoch X., Ebdon J., Gantzer C., Lucena F., Ottoson J., Kourtis C., Iversen A., Kühn I., Moce L., Muniesa M., Schwartzbrod J., Skraber S., Papageorgiou G. T., Taylor H. D., Wallis J. and Jofre J. (2004). Tracking the origin of faecal pollution in surface water: an ongoing project within the European Union research programme. Journal of Water and Health, 2, 249-260.

Cole D., Long S. C. and Sobsey M. D. (2003). Evaluation of F+ RNA and DNA coliphages as source-specific indicators of fecal contamination in surface waters. Applied Environmental Microbiology, 69(11), 6507-6514.

Contreras-Coll N., Lucena F., Mooijman K., Havelaar A., Pierzo V., Boque M., Gawler A., Höller C., Lambiri M., Mirolo G., Moreno B., Niemi M., Sommer R., Valentin B., Wiedenmann A., Young V. and Jofre J. (2002). Occurrence and levels of indicator bacteriophages in bathing waters throughout Europe. Water Research, 36(20), 4963-4974.

Gourmelon M., Caprais M.P., Segura R., Le Mennec C., Lozach S., Piriou J.Y. and Rince A., (2007). Evaluation of two library-independent Microbial Source Tracking methods to identify sources of fecal contamination in French estuaries. Applied Environmental Microbiology, 73, 48574866.

Gilpin B., James T., Nourozi F., Saunders D., Scholes P., and Savill M.(2003). The use of chemical and molecular microbial indicators for faecal source identification. Water Science and Technology, 47, 39-43.

Hsu F.C., Shieh Y.S., van Duin J., Beekwilder M.J. and Sobsey M.D. (1995). Genotyping malespecific RNA coliphages by hybridization with oligonucleotide probes. Applied Environmental Microbiology, 61, 3960-3966.

Layton A., McKay L., Williams D., Garrett V., Gentry R. and Sayler G. (2006). Development of Bacteroides 16S rRNA gene TaqMan-based real-time PCR assays for estimation of total, human, and bovine fecal pollution in water. Applied Environmental Microbiology, 72, 4214-4224.

Long S.C. and Sobsey M.D. (2004). A comparison of the survival of F+RNA and F+DNA coliphages in lake water microcosms. Journal of Water and Health, 2(1), 15-22.

Love D. C. and Sobsey M. D. (2007). Simple and rapid F+ coliphage culture, latex agglutination, and typing assay to detect and source track fecal contamination Applied Environmental Microbiology, 73(13), 4110-4118. 
Mendez J., Audicana A., Isern A., Llaneza J., Moreno B., Tarancon M.L., Jofre J. and Lucena F. (2004). Standardised evaluation of the performance of a simple membrane filtration-elution method to concentrate bacteriophages from drinking water. Journal of Virological Methods, 117, 19-25.

Mieszkin S., Furet J.-P., Corthier G. and Gourmelon M. (2009). Estimation of pig fecal contamination in a river catchment by Real-Time PCR using two pig-specific Bacteroidales 16S rRNA genetic markers. Applied Environmental Microbiology, 75(5) 3045-3054.

NF EN ISO 10705-1 (2001). Water quality. Detection and enumeration of bacteriophages. Part 1: Enumeration of $\mathrm{F}$ specific RNA.bacteriophages.

NF EN ISO 9308-3. (1999). Water quality. Detection and enumeration of Escherichia coli and coliform bacteria in surface and waste water. Miniaturized method (Most Probable Number) by inoculation in liquid medium.

Ogorzaly, L., and Gantzer, C. (2006). Development of real-time RT-PCR methods for specific detection of F-specific RNA bacteriophage genogroups: Application to urban raw wastewater. Journal of Virological Methods.

Regulation (EC) $\mathrm{N}^{\circ} 854 / 2004$ of European Parliament and of the council of 29 april 2004.Laying down specific rules for the organisation of official controls on products of animal origin intended for human consumption. Official Journal of the European Union L139.

Reischer G.H., Kasper D.C., Steinborn R., Mach R.L. and Farnleitne, A.H. (2006). Quantitative PCR method for sensitive detection of ruminant fecal pollution in freshwater and evaluation of this method in Alpine karstic regions. Applied Environmental Microbiology, 72, 5610-5614.

Reischer GH, Haider JM, Sommer R, Stadler H, Keiblinger KM, Hornek R, Zerobin W, Mach RL, Farnleitner AH.(2008). Quantitative microbial faecal source tracking with sampling guided by hydrological catchment dynamics. Environmental Microbiology, 10 (10),2598-608.

Savichtcheva O., Okayama N. and Okabe S. (2007). Relation between Bacteroides 16S rRNA genetic markers and presence of bacterial enteric pathogens and conventional fecal indicators. Water Research, 41(16), 3615-3628.

Seurinck S., Defoirdt T., Verstraete W. and Siciliano S.D. (2005). Detection and quantification of the human-specific HF183 Bacteroides16S rRNA genetic marker with real-time PCR for assessment of human faecal pollution in freshwater. Environmental Microbiology, 7(2), 249-259.

Seurinck S., Verdievel M., Verstraete W. and Siciliano S.D. (2006). Identification of human fecal pollution sources in a coastal area: a case study at Oostende. Journal of Water and Health, 4(2), 167-75

Schaper, M., Duran, A. E., and Jofre, J. (2002). Comparative Resistance of Phage Isolates of Four Genotypes of F-Specific RNA Bacteriophages to Various Inactivation Processes. Applied Environmental Microbiology, 68(8), 3702-3707.

Stapleton C.M., Wyer M.D., Kay D., Crowther J., Mc Donald A.T., Walters M., Gawler A. and Hindle T. (2007). Microbial source tracking: a forensic technique for microbial source identification? Journal of Environmental Monitoring, 9, 427-439.

\section{Acknowledgments}

This work was supported by Gerrico program, SMIDAP and Région Pays de la Loire. 